\title{
HARAPAN MASYARAKAT DAN TANTANGAN DALAM PENDIDIKAN
}

\author{
Oktober Tua Aritonang \\ Sekolah Tinggi Agama Kristen Negeri (STAKN) \\ Jl. Raya Tarutung-Siborongborong Km. 11 Silangkitang \\ Tapanuli Utara Sumatera Utara 2241 \\ Email: oktoaritonang@gmail.com
}

\begin{abstract}
Abstrak:
Tulisan ini bertujuan untuk mengkaji harapan-harapan masyarakat dan tantangan dalam bidang pendidikan yang sampai saat ini masih dihadapi sekaligus memaparkan beberapa langkah solusi yang dapat dilakukan guna menjawab harapan dan tantangan tersebut. Untuk memperoleh data atau informasi yang dibutuhkan, dalam kajian ini digunakan metode kepustakaan (library research), yaitu berupa rujukan-rujukan literatur pakar pendidikan. Dari hasil kajian, disimpulkan bahwa beberapa harapan masyarakat dalam bidang pendidikan di antaranya yaitu menginginkan pemerataan pendidikan, Ujian Nasional (UN) bukan syarat mutlak kelulusan, dan keinginan agar kebijakan pendidikan mempunyai arah yang jelas. Salah satu tantangan dalam pendidikan yaitu adanya diskriminasi dalam penyelenggaraan pendidikan. Beberapa solusi peninjauan kembali kebijakan pemerintah, penambahan pagu anggaran, pembentukan karakter, profesionalisme guru, sarana dan prasarana, dan pendidikan berbasis masyarakat.
\end{abstract}

\begin{abstract}
:
This paper aims to examine society's expectations and challenges in the field of education is still facing solutions as well as explain some of the steps that can be done to respond to the expectations and challenges. To obtain the data or information is needed, the method used in this study literature (library research), in the form of literature references education experts. From the results of the study, it was concluded that some people's expectations in the areas of education among the wanted educational equity, the National Examination (UN) is not an absolute requirement of graduation, and the desire for education policy has a clear direction. And one of the challenges in the education of the existence of discrimination in education.
\end{abstract}

Kata kunci:

Harapan masyarakat, tantangan dalam pendidikan

JIKA membicarakan pengembangan sistem pendidikan berarti berkaitan dengan seluruh perubahan atau penyempurnaan atas kebijakan pendidikan yang sifatnya makro sampai dengan penyempurnaan kurikulum dan proses pembelajaran di sekolah atau lembaga perguruan tinggi (mikro) yang dilaksanakan oleh guru atau dosen. Artinya bagaimana upaya pemerintah dalam meningkatkan mutu pendidikan melalui pengembangan sistem pendidikan dan pembelajaran tersebut. Reformasi pendidikan yang seyogyanya menuntut terjadinya perubahan secara sistemik hanya masih sebatas seolah-olah. Artinya seolah-olah pendidikan telah dijadikan pilar primadona, namun pada prakteknya belum terlaksana. 
Kenyataannya sampai saat ini dalam penyelenggaraan pendidikan masih terjadi kecenderungan sebagai berikut: pertama, memberlakukan peserta didik berstatus sebagai objek, di mana guru berfungsi sebagai pemegang otoritas tertinggi keilmuan dan indoktrinator. Kedua, materi ajar bersifat subject oriented, dan ketiga, manajemen pendidikan masih baru dalam transisi dari sentralistik ke desentralistik. Akibatnya pendidikan mengisolasi diri dari kehidupan real yang ada di luar sekolah, kurang relevan antara yang diajarkan dengan kebutuhan dalam perkerjaan, terlalu terkonsentrasi pada pengembangan intelektual yang tidak sejalan dengan pengembangan individu sebagai satu kesatuan yang utuh dan berkepribadian. Keempat, proses pembelajaran didominasi oleh tuntutan untuk menghapalkan dan menguasai pelajaran sebanyak mungkin guna menghadapi ujian atau tes.

Mutu pendidikan bangsa Indonesia belum mencapai posisi yang baik jika dibandingkan dengan negara-negara lain. Padahal sektor ini sangat diperlukan untuk meningkatkan kualitas sumber daya manusia yang dibutuhkan untuk membangun bangsa. Akibat rendahnya mutu pendidikan sekarang, sumber daya manusia yang ada kurang memiliki daya saing pada tingkat dunia. Tentunya jika masalah ini tidak dicarikan solusi secepatnya, akan memberikan dampak yang lebih besar terhadap sektor-sektor lainnya. Demokrasi pendidikan, keterbukaan, desentralisasi, otonomisasi, dan sebagainya dalam menyelenggarakan pendidikan secara resmi dan normatif sudah disosialisasikan secara meluas. Namun kelihatannya, lagi-lagi demokrasi tidak berlaku dalam masyarakat yang budaya akademiknya masih rendah dan sumber daya manusianya belum berpendidikan tinggi.

Selain itu dalam kenyataannya sistem pendidikan masih highly centralized dan diskriminatif. Pemerintah dengan sangat kuat melaksanakan satu sistem pendidikan nasional lengkap dengan penyelenggaraan sekolah-sekolah atau perguruan-perguruan tinggi sebagai unit pelaksanaannya. Semua yang diselenggarakan masyarakat harus mengikutinya sebagai subsistem dari satu sistem pendidikan nasional. Ibarat dalam sistem keluarga di rumah tangga, anak adalah subsistem dalam keluarga. Namun jika anak tidak berkesempatan hidup dengan jati dirinya sebagai suatu sistem tersendiri, anak tidak akan pernah mampu memberikan kontribusi yang bermakna bagi keluarganya. Justru kemandirian anak dan sukses kehidupannya di luar keluarga ibubapaknya, mereka makin berdaya mengharumkan sistem keluarganya.

Sampai saat ini ada banyak polemik yang terjadi dalam pelaksanaan pendidikan di Indonesia. Mulai dari masalah ujian nasional yang sampai saat ini masih menjadi delik, tumbuhnya bisnis-bisnis pendidikan yang mau tidak mau semakin membuat rakyat yang tidak mampu semakin terpuruk. Pendidikan hanyalah bagi mereka yang telah memiliki ekonomi yang kuat, sedangkan bagi masyarakat miskin, pendidikan hanyalah suatu mimpi. Banyak mahasiswa yang diharapkan menjadi calon intelektual muda, terpaksa cuti kuliah karena keterbatasan ekonomi keluarga. Lain lagi bagi siswa SLTP dan SLTA yang putus sekolah, masalahnya akan lebih rumit. Belum lagi 
terjadinya kemerosotan moral siswa yang semakin hari semakin memprihatinkan seperti tawuran, menghina guru, bolos, memakai narkoba, dan melakukan tindakan amoral lainnya.

\section{PEMBAHASAN}

\section{Harapan Masyarakat dalam Bidang Pendidikan}

Secara garis besar harapan masyarakat dalam pendidikan telah tertuang dalam beberapa peraturan yuridis mulai dari Pembukaan UUD RI 1945 alinea keempat ditegaskan bahwa salah satu tujuan nasional adalah mencerdaskan kehidupan bangsa, dan dalam pasal 31 UUD RI 1945 ditegaskan pula bahwa (1) Setiap warga negara berhak mendapat pendidikan, (2) Setiap warga negara wajib mengikuti pendidikan dasar dan pemerintah wajib membiayainya, (3) Pemerintah mengusahakan dan menyelenggarakan satu sistem pendidikan nasional yang meningkatkan keimanan dan ketakwaan serta ahlak mulia dalam rangka mencerdaskan kehidupan bangsa yang diatur dengan undang-undang, (4) Negara memprioritaskan anggaran pendidikan sekurang-kurangnya dua puluh persen dari anggaran pendapatan dan belanja negara serta dari anggaran pendapatan dan belanja daerah untuk memenuhi kebutuhan penyelenggaraan pendidikan nasional, dan (5) Pemerintah memajukan ilmu pengetahuan dan teknologi dengan menjunjung tinggi nilai-nilai agama dan persatuan bangsa untuk kemajuan peradaban serta kesejahteraan umat manusia. Selanjutnya dipertegas kembali dalam dalam Undang-Undang RI Nomor 20 Tahun 2003 dalam pasal 3 Pendidikan nasional berfungsi mengembangkan kemampuan dan membentuk watak serta peradaban bangsa, yang bermartabat dalam rangka mencerdaskan kehidupan bangsa, bertujuan untuk berkembangnya potensi peserta didik agar menjadi manusia yang beriman, dan bertakwa kepada Tuhan Yang Maha Esa, berakhlak mulia, sehat, berilmu, cakap, kreatif, mandiri, dan menjadi warga negara yang demokratis serta bertanggung jawab. Pada pasal 4 dinyatakan bahwa (1) Pendidikan diselenggarakan secara demokratis dan berkeadilan, serta tidak diskriminatif dengan menjunjung tinggi hak asasi manusia, nilai keagamaan, nilai kultural, dan kemajemukan bangsa, (2) Pendidikan diselenggarakan sebagai satu kesatuan yang sistemik dengan sistem terbuka dan multimakna, (3) Pendidikan diselenggarakan sebagai suatu proses pembudayaan dan pemberdayaan peserta didik yang berlangsung sepanjang hayat, (4) Pendidikan diselenggarakan dengan memberi keteladanan, membangun kemauan, dan mengembangkan kreativitas peserta didik dalam proses pembelajaran, (5) Pendidikan diselenggarakan dengan mengembangkan budaya membaca, menulis, dan berhitung bagi segenap warga masyarakat, (6) Pendidikan diselenggarakan dengan memberdayakan semua komponen masyarakat melalui peran serta dalam penyelenggaraan dan pengendalian mutu layanan pendidikan, dan masih banyak peraturan-peraturan lainnya yang mengakomodasi harapan masyarakat dalam pendidikan.

Jadi, berdasarkan beberapa dasar hukum yang telah disebutkan ada beberapa harapan masyarakat dalam bidang pendidikan yaitu: 


\section{Pemerataan Pendidikan}

Pemerataan pendidikan maksudnya pendidikan dapat dinikmati oleh siapa saja, kapan saja, dan di mana saja. Jadi, penyelenggaraan pendidikan tidak hanya ditujukan kepada golongan masyarakat mampu, tetapi hendaknya dapat dinikmati oleh semua lapisan masyarakat. Selain itu, proses pendidikan dapat diakses tidak hanya dari ruang sekolah saja (tatap muka) tetapi dapat diperoleh dari jarak jauh (SMP dan SMA Terbuka, Universitas Terbuka), home schooling (bentuk pendidikan alternatif) dan pembelajaran berjaringan (E-learning), karena proses pendidikan yang telah mengglobal tidak mengenal lagi batas-batas geografi dan memberikan kebebasan pada peserta didik mengakses dari berbagai aneka sumber (BEBAS).

\section{Ujian Nasional Bukan Syarat Mutlak Kelulusan}

Secara umum sebagian kalangan masyarakat sangat tidak setuju dengan ujian nasional sebagai syarat kelulusan untuk anak tingkat SD, SMP, dan SMA. Masyarakat awam sekalipun kini telah memahami bahwa ujian nasional merupakan implementasi untuk mengetahui standar evaluasi (penilaian). Adalah sangat tidak adil menetapkan perolehan rata-rata nilai akhir ujian nasional minimal 5,5 agar seorang siswa lulus, sementara proses pembelajaran, sarana dan prasarana sekolah, dan faktor lainnya, belum dikelola dengan baik. Selain itu, materi ujian nasional pun semata-mata hanya mengukur kemampuan kognitif. Harapan masyarakat adalah sebaiknya ujian nasional hanya untuk evaluasi untuk mendapatkan informasi (pemetaan) kualitas proses pembelajaran yang ada di tiap satuan pendidikan dan tiap daerah bukan sebagai syarat mutlak kelulusan anak.

\section{Kebijakan Pendidikan Mempunyai Arah yang Jelas}

Ada banyak kebijakan yang dirasakan masyarakat cukup membingungkan. Misalnya dalam suatu peraturan tentang pendidikan ditegaskan bahwa pendidikan dasar dibiayai oleh negara, namun di sisi lain ada juga peraturan pendidikan yang mengharuskan siswa membayar mahal agar anaknya dapat sekolah di suatu sekolah tingkat SD atau SMP. Selain itu, adanya pergantian buku-buku pegangan anak yang terus terjadi pada hampir setiap tahun ajaran ataupun semester. Sehingga buku yang baru saja dipakai satu tahun tidak dapat lagi dipakai oleh anaknya yang lain hanya karena kebijakan tentang kurikulum pendidikan yang terus silih berganti. Hal ini tentunya sangat merugikan orang tua siswa, terutama dari kalangan masyarakat ekonomi kurang mampu.

\section{Pendidikan Berbasis Masyarakat (Community based education)}

Sesuai dengan tuntutan masyarakat demokrasi, maka masyarakat harus ikut serta secara aktif di dalam menyelenggarakan pendidikannya. ${ }^{1}$ Pendidikan berbasis masyarakat bukanlah hal baru di Indonesia karena telah diterapkan ratusan tahun yang lalu melalui sistem pendidikan yang disebut pesantren. Pendidikan berbasis masyarakat secara jelas ditegaskan dalam Undang-Undang RI Nomor 20 Tahun 2003 tentang Sistem Pendidikan Nasional BAB XV pada bagian dua, Pasal 55, (1) Mas- 
yarakat berhak menyelenggarakan pendidikan berbasis masyarakat pada pendidikan formal dan nonformal sesuai dengan kekhasan agama, lingkungan sosial, dan budaya untuk kepentingan masyarakat, (2) Penyelenggara pendidikan berbasis masyarakat mengembangkan dan melaksanakan kurikulum dan evaluasi pendidikan, serta manajemen dan pendanannya sesuai dengan standar nasional pendidikan, (3) Dana penyelenggaraan pendidikan berbasis masyarakat dapat bersumber dari penyelenggara, masyarakat, Pemerintah, Pemerintah Daerah dan/atau sumber lain yang tidak bertentangan dengan peraturan perundang-undangan yang berlaku, (4) Lembaga pendidikan berbasis masyarakat dapat memperoleh bantuan teknis, subsidi dana, dan sumber daya lain secara adil dan merata dari Pemerintah dan/atau pemerintah daerah, dan (5) Ketentuan mengenai peran serta masyarakat sebagaimana dimaksud pada ayat (1), ayat (2), ayat (3), dan ayat (4) diatur lebih lanjut dengan peraturan pemerintah.

Dari pasal ini, terlihat bahwa pendidikan berbasis masyarakat dapat diselenggarakan dalam jalur formal ataupun nonformal, serta dasar dari pendidikan berbasis masyarakat adalah kebutuhan dan kondisi masyarakat, serta masyarakat diberi kewenangan yang luas untuk mengelolanya. Oleh karena itu, dalam menyelenggarakannya perlu memerhatikan tujuan yang sesuai dengan kepentingan masyarakat setempat. Tujuan pendidikan nonformal berbasis masyarakat dapat mengarah pada isu-isu masyarakat yang khusus seperti pelatihan karir, perhatian terhadap lingkungan, budaya dan sejarah etnis, kebijakan pemerintah, pendidikan, politik dan kewarganegaraan, pendidikan keagamaan, pendidikan bertani, penanganan masalah kesehatan serta korban narkotika, AIDS dan sejenisnya.

Pemahaman sekolah berbasis masyarakat dapat diperluas menjadi penyelenggaraan pendidikan oleh masyarakat yang bersifat nonformal. Hal ini dapat menjadi salah satu upaya yang dilakukan oleh pemerintah untuk meningkatkan angka partisipasi pendidikan guna menunjang wajib belajar melalui pendidikan kesetaraan. Pendidikan kesetaraan adalah jalur pendidikan nonformal dengan standar kompetensi lulusan yang sama dengan sekolah formal. Pendidikan kesetaraan meliputi Program Paket A setara SD, Paket B setara SMP, dan Paket C setara SMA ditujukan bagi peserta didik yang berasal dari masyarakat yang kurang beruntung, tidak pernah sekolah, putus sekolah dan putus lanjut, serta usia produktif yang ingin meningkatkan pengetahuan dan kecakapan hidup, dan warga masyarakat lain yang memerlukan layanan khusus dalam memenuhi kebutuhan hidupnya sebagai dampak dari perubahan peningkatan taraf hidup, ilmu pengetahuan dan teknologi.

\section{Belajar untuk Mengembangkan Kreativitas dan Kemandirian}

Proses pembelajaran yang ada diharapkan mengembangkan kemampuan peserta didik untuk memecahkan masalah akademik dan praktis yang dihadapinya. Kemampuan ini sering disebut dengan "Belajar Menemukan" (discovery learning) atau creativity learning. Prinsip ini dalam pelaksanaannya diimplementasikan dengan berkurangnya penjelasan atau ceramah oleh guru dan mencari pemecahan masalah oleh peserta didik. ${ }^{2}$ 
Selanjutnya, proses pembelajaran yang diberikan pada peserta didik diharapkan mampu mengembangkan sikap kemandirian mereka. Sama halnya dengan falsafah pendidikan Mohammad Syafei yang salah satunya menekankan pada sikap mandiri. Seseorang mempunyai nilai yang tinggi dalam masyarakat jika dia dapat menunjukkan kemandiriannya. Jadi, pendidikan kemandirian tidak menekankan pengembangan intelektual saja tetapi lebih menekankan pada praktek pekerjaan tangan. ${ }^{3}$

\section{Belajar sebagai Proses Pembudayaan (Perkembangan Kepribadian)}

Pendidikan seharusnya merupakan suatu proses pembudayaan yang diarahkan kepada berkembangnya kepribadian seorang yang mandiri sebagai anggota masyarakat demokratis. ${ }^{4}$ Perkembangan yang dimaksud merupakan perkembangan segala aspek kepribadian secara utuh, bukan hanya menekankan hanya pada aspek kognitif saja, melainkan keyakinan, minat, dan nilai yang membentuk pribadi seseorang. Dengan memperoleh pendidikan, seorang anak tidak hanya diharapkan cerdas tetapi juga memiliki sikap dan perilaku yang baik. Melalui pendidikan seseorang akan mampu bertindak serasi dan selaras dengan lingkungannya.

Selanjutnya, salah satu asas Perguruan Taman Siswa yang didirikan oleh Ki Hajar Dewantoro menegaskan bahwa pendidikan sebagai usaha kebudayaan bertujuan untuk menumbuhkan kepribadian peserta didik secara keseluruhan dalam kodratnya dengan pengaruh budaya sekelilingnya yang dapat memajukan hidup alam sekitarnya menuju pada peradaban kemanusiaan. ${ }^{5}$ Salah satu contoh kecil bahwa melalui proses pembelajaran di sekolah, siswa tingkat SD pun dapat dibentuk karakternya sebagai orang yang demokratis. Misalnya pada rapat siswa kelas VI hendak menentukan salah satu dari tiga tempat wisata yang akan dikunjungi sebagai perayaan perpisahan di sekolah. Maka kelompok siswa yang pilihannya tidak menang tetap mau berjabatan tangan dengan kelompok yang pilihannya dikabulkan. Dengan peristiwa semacam ini yang dibiasakan sejak anak masih di tingkat SD, tentulah di masa yang akan datang tidak ada lagi seorang kandidat bupati yang kalah membuat kerusuhan di tempatnya sendiri hanya sebagai kompensasi ketidakpuasannya atas kekalahannya tersebut. Beliau juga menyampaikan bahwa pendidikan (pembelajaran mikro) sebagai proses pembudayaan maksudnya tidak hanya mentransfer pengetahuan tetapi lebih dari itu adalah mentransformasi nilai kepribadian, misalnya dari yang malas menjadi rajin, dari yang bersikap acuh menjadi peduli dan sebagainya.

\section{Sumber Daya Pendidikan yang Profesional dan Sarana Penunjang yang Memadai}

Desentralisasi dan demokratisasi proses pendidikan memerlukan tenaga-tenaga yang terampil dan profesional. Pada masa sebelumnya proses pendidikan telah mematikan berpikir kritis dan inisiatif. Artinya proses pendidikan tidak diarahkan untuk mengembangkan berpikir kritis dan inovatif. Kondisi ini akan semakin menjauhkan peserta didik dari keterlibatannya dengan kehidupan nyata. Para pendidik yang ada saat ini masih lemah dilihat dari berbagai sisi, karena itu diperlukan pengembangan profesi guru maupun dosen yang profesional. 
Selain aspek sumber dayanya, masyarakat juga mengharapkan agar pemerintah juga membenahi sarana penunjang yang dibutuhkan dalam proses pembelajaran seperti penambahan jumlah sekolah, alat, bahan peraga, literatur perpustakaan sekolah, jaringan internet dan lainnya, sehingga memungkinkan terselenggaranya proses pembelajaran dengan maksimal.

\section{Perlunya Penambahan Anggaran Pendidikan untuk Pembenahan Seluruh Komponen SNP}

Persoalan anggaran pendidikan yang utama adalah alokasi yang memang telah menjadi masalah yang cukup pelik di Indonesia. Besaran angka untuk menentukan besaran jumlah dana pendidikan secara resmi muncul dalam amandemen UndangUndang Dasar Republik Indonesia 1945 Amandemen pasal 34 ayat 1, yang menyatakan bahwa anggaran pendidikan minimal 20 persen dari nilai APBN dan APBD.

Lebih lanjut melalui kebijakan pendidikan di Indonesia yang tertuang dalam Undang-Undang RI Nomor 20 Tahun 2003 Ayat (49), mensyaratkan pengeluaran pemerintah di bidang pendidikan harus paling rendah sebesar 20 persen dari total anggaran pemerintah pusat maupun daerah, dan yang dimaksud 20 persen adalah di luar gaji guru dan biaya pendidikan kedinasan. Namun demikian besaran pagu anggaran pendidikan yang sekarang $20 \%$ dari APBN dan APBD dirasakan tidak cukup untuk membenahi pendidikan terutama sarana dan prasarana yang tercakup dalam komponen SNP.

\section{Permasalahan yang Menjadi Tantangan dalam Pendidikan}

\section{Terjadinya Diskriminasi dalam Penyelenggaraan Pendidikan}

Dewasa ini telah berdiri sekolah-sekolah plus, sekolah berstandar internasional, badan hukum pendidikan, ataupun pendidikan tinggi dalam bentuk badan hukum milik negara (BHMN). Hal ini menunjukkan adanya kecenderungan terhadap neopositivisme di dalam pendidikan nasional. Pandangan ini banyak dipengaruhi oleh paradigma ekonomi. Pendidikan yang berkualitas adalah pendidikan yang meminta biaya yang mahal. Dengan sendirinya pandangan ini akan menutup pintu bagi kelompok masyarakat yang tidak mampu membiayai pendidikan yang berkualitas. Hal ini ditandai dengan semakin banyaknya berdiri sekolah-sekolah plus dimulai dari tingkat taman kanak-kanak sampai tingkat sekolah menengah, pengembangan sekolah pemerintah pada tingkat pendidikan dasar menjadi sekolah bertaraf internasional (SBI) dan untuk perguruan tinggi hanya dapat menerima anak-anak dari golongan keluarga yang kaya dengan adanya kebijakan tentang badan hukum pendidikan.

Sekolah-sekolah plus bertaraf internasional bekerja sama dengan lembagalembaga pendidikan luar negeri dengan mengorbankan bahasa nasional yakni bahasa Indonesia. Secara singkat kebijakan pendidikan diarahkan pada outward looking, yang akan mengakibatkan kehilangan fokus pendidikan nasional khususnya kekaburan misi yang tercantum dalam UUD RI yaitu mencerdaskan kehidupan bangsa, atau dengan kata lain pendidikan nasional kehilangan rohnya. ${ }^{6}$ 
Kenyataannya pemerintah memberikan payung hukum bagi pelaksanaan rintisan sekolah bertaraf internasional ( RSBI) dan sekolah bertaraf internasional (SBI) yaitu UU RI No. 20 tahun 2003 pasal 50 yang berbunyi Pemerintah dan/atau Pemerintah Daerah menyelenggarakan sekurang-kurangnya satu sekolah pada semua jenjang pendidikan untuk dikembangkan menjadi Sekolah yang Bertaraf Internasional (SBI). Peraturan Pemerintah RI Nomor 19 tahun 2005 tentang Standar Nasional Pendidikan dalam Pasal 61 Ayat (1) menyatakan bahwa: Pemerintah bersama-sama Pemerintah Daerah menyelenggarakan sekurang-kurangnya satu sekolah pada jenjang pendidikan dasar dan sekurang-kurangnya satu sekolah pada jenjang pendidikan menengah untuk dikembangkan menjadi Sekolah Bertaraf Internasional (SBI). Namun kebijakan ini merugikan warga negara yang kurang beruntung secara ekonomi tetapi memiliki kemampuan akademik yang bagus. Mereka kesulitan menyekolahkan anaknya di sekolah tersebut karena ketiadaan biaya. Akibatnya mereka bersekolah di sekolah berstandar nasional atau putus sekolah. Seharusnya Depdiknas memberikan beasiswa untuk belajar di RSBI dan SBI bagi warga negara seperti itu. Dalam Undang-Undang RI Nomor 20 Tahun 2003 pasal 5 ayat (1) ditegaskan bahwa setiap warga negara mempunyai hak yang sama untuk memperoleh pendidikan yang bermutu.

Selain itu, munculnya kebijakan pemerintah yang mengeluarkan undangundang yang mengatur lembaga-lembaga pendidikan pemerintah sebagai badan hukum pendidikan (BHP), bahwa lembaga pendidikan harus membiayai sendiri berbagai aktivitasnya. Konsekuensi dari undang-undang ini jelas nyata bahwa biaya pendidikan terutama harus ditanggung oleh peserta didik. Tentunya hal ini merupakan kendala bagi anak dari keluarga tidak mampu. Gejala komersialisasi pendidikan tinggi ini mulai kelihatan di Indonesia sejak lahirnya beberapa universitas sebagai badan hukum milik negara (BHMN). Sebagaimana yang dinyatakan Rektor Universitas Indonesia bahwa pemerintah sebenarnya hanya memberikan $1 / 5$ dari kebutuhan dana yang dibutuhkan, sedangkan di negara-negara maju pemerintah menyediakan sampai $90 \%$ dananya.

Upaya untuk meningkatkan mutu pendidikan tinggi dengan status BHMN dan kemudian menjadi BHP, sebenarnya menunjukkan keengganan pemerintah untuk mengeluarkan dana bagi pengembangan pendidikan tinggi. Sebagai konsekuensinya pendidikan tinggi dengan status BHMN mencari dana antara lain dengan cara menaikkan uang kuliah yang berarti membebani mahasiswa, apalagi mahasiswa yang berasal dari golongan ekonomi tidak mampu. Jelaslah bahwa ini bukanlah merupakan tujuan pendidikan sebagaimana yang digariskan dalam UUD 1945 RI dan UU RI No.20 Tahun 2003. ${ }^{7}$

\section{Proses Pembelajaran Hanya Menekankan Aspek Kognitif (Learn to Know) dan Belum Membangun Kepribadian (Pembudayaan)}

Proses pembelajaran yang dilangsungkan guru ataupun dosen masih mengarah pada teacher oriented, siswa hanya mendengar penjelasan guru dan sesekali diberi pertanyaan untuk diberikan jawabannya. Siswa tidak diberikan kesempatan untuk mengembangkan kreativitasnya. Dengan model pembelajaran yang demikian tentu- 
nya tidak akan dapat membangun kepribadian siswa utuh, karena mereka tidak diarahkan untuk mandiri, saling menghargai dan memberi dengan yang lain, maupun sikap bekerja sama.

Kebanyakan para lulusan yang dihasilkan oleh suatu lembaga pendidikan, baik di tingkat SMA ataupun tingkat sarjana hanya sebatas menyentuh satu pilar pendidikan yaitu belajar mengetahui (learning to know), belum menyentuh empat pilar lainnya belajar untuk beriman dan bertakwa kepada Tuhan Yang Mahaesa (learning to believe and convince the almighty God), belajar berbuat (learning to do), belajar menjadi seseorang (learning to be), dan belajar hidup bermasyarakat (learning to live together). Para lulusan hanya sekadar memperoleh selembar ijazah tanpa memiliki keterampilan dari apa yang telah dipelajarinya semasa sekolah. Ini mau tidak mau seseorang itu tidak dapat berbuat apapun setelah dia menghadapi dunia realita. Akibatnya, setiap tahunnya angka tingkat pengangguran usia produktif terus bertambah.

\section{Masih Adanya Warga Masyarakat yang Belum Mendapat Kesempatan Memperoleh Pendidikan}

Walaupun pemerintah telah berusaha memberikan pelayanan pendidikan nonformal yang setara dengan sekolah formal kepada masyarakat yakni melalui Paket A, B, dan Paket $C$, namun sampai saat ini belum seluruh anggota masyarakat berkesempatan untuk mendapatkannya. Khususnya di daerah-daerah pedalaman seperti di Pulau Batu Nias, kebanyakan warga masyarakatnya belum melek huruf.

\section{Kebijakan Pendidikan Tidak Mempunyai Arah yang Jelas}

Hal ini ditandai dengan pergantian kurikulum beberapa kali yakni, kurikulum pada era Menteri Pendidikan Suwandi (1947), Mashuri (1968), Syarif Thajeb (1975), Nugroho Notosusanto (1984), Wardiman Djojonegoro (1994), Malik Fajar (2004), dan Bambang Sudibyo (2006) tidak memberikan prestasi pendidikan nasional yang gemilang. Praksis pendidikan tidak pernah lekang dari 'uji coba'. Kebijakan dan kebijaksanaan mudah berubah. Kurikulum pendidikan nasional yang silih berganti tanpa dilakukan terlebih dahulu evaluasi mendalam. Akibatnya, terjadi kekacauan di lapangan terutama bagi pelaksana proses pendidikan yaitu guru. Akhirnya yang dirugikan atau menderita adalah siswa yang terus-menerus menjadi kelinci percobaan. Suatu kurikulum memang seharusnya berganti minimal sekali dalam lima tahun karena perubahan tuntutan kehidupan, kemajuan ilmu pengetahuan, dan perubahan masyarakat. 8

Selain hal tersebut, ada juga beberapa kebijakan pemerintah dalam bidang pendidikan yang tertuang dalam suatu peraturan perundang-undangan saling kontroversi, misalnya dalam UUD RI 1945 Amandemen pada pasal 31 ayat 1 dan 2, yaitu tentang hak warga negara memperoleh pendidikan dan dibiayai oleh negara, dan Undang-Undang RI Nomor 20 Tahun 2003 pasal 5 ayat (1) ditegaskan bahwa setiap warga negara mempunyai hak yang sama untuk memperoleh pendidikan yang bermutu. Sementara itu, di satu sisi dalam UU RI No. 20 tahun 2003 pasal 50 dan Peraturan Pemerintah RI Nomor 19 tahun 2005 tentang Standar Nasional Pendidikan 
dalam Pasal 61 Ayat (1), yaitu tentang pendirian sekolah bertaraf internasional. Akibat adanya sekolah jenis ini, ada kelompok masyarakat yang tidak dapat menikmatinya karena ketiadaan biaya.

\section{Polemik dalam Sistem Standarisasi}

Sampai saat ini proses upaya untuk melakukan standarisasi pendidikan khususnya standarisasi hasil belajar, masih tetap berlangsung dengan masih diselenggarakannya UN walaupun ada saling kontroversi antara satu dengan yang lain. Setiap siswa harus mampu memperoleh nilai rata-rata UN 5,5 yang terdiri dari beberapa mata pelajaran tertentu baru memperoleh sertifikat kelulusan. Mengapa ini masalah? Ada unsur ketidakwajaran dalam pelaksanaan UN tersebut, sebab bagaimana mungkin menstandarkan hasil belajar dari banyak sekolah dengan kondisi yang masingmasing berbeda, hanya dengan satu alat ukur yang sama. Bahkan sebenarnya menurut beberapa pihak, seharusnya sarana dan prasarana serta kualifikasi gurunya terlebih dahulu distandarisasi, barulah terhadap hasil belajarnya.

Jika UN diselenggarakan sebagai syarat kelulusan tentu hal ini merupakan proses 'mematikan' kreativitas dan bakat siswa. Karena setiap siswa sudah tentu memiliki potensi, bakat, dan minat yang berbeda-beda. "Ibarat seekor burung elang" bakatnya yang dominan adalah lihai terbang di udara, namun burung tersebut dipaksa harus dapat berenang dalam air dengan nilai memuaskan, sudah tentu pemaksaan ini akan berakibat fatal. Demikian sebaliknya, seekor ikan yang bakatnya berenang, tetapi harus dapat pula terbang seperti burung elang tadi, maka ini akan berdampak negatif.

Inilah yang terjadi dalam dunia pendidikan. Jadi tidaklah heran jika ada pemberitaan tentang seorang anak sekolah SD bunuh diri hanya karena ketakutannya tidak lulus dalam UN, walaupun hasilnya belum diumumkan. Sama halnya dengan seekor ikan atau burung elang tadi, siswa akan menjadi trauma dengan adanya UN sebagai syarat kelulusan. Paling tidak penyelenggaraan UN itu hanya sebatas untuk menyamakan pesepsi antara guru bidang studi untuk mata pelajaran yang paralel atau sama di beberapa daerah dalam hal memberi angka atau nilai siswa. Artinya nilai 7 misalnya untuk mata pelajaran bahasa Inggris di Jakarta sama bobotnya dengan nilai 7 yang diberikan guru di Medan untuk mata pelajaran tersebut.

Apa yang dilakukan anak-anak sekolah tingkat SMP maupun SMA selesai menghadapi ujian akhir sekolah dan ujian nasional (UN) ? Mereka melakukan aksi coret-mencoret kostum seragam sekolah yang dikenakan, serta sambil melompatlompat kegirangan seperti orang yang kurang waras. Ternyata motivasi mereka berbuat seperti itu adalah sebagai ungkapan kegembiraan mereka atas bebasnya dari 'belenggu penjajahan' selama menimba ilmu di sekolahnya.

Dari kasus di atas kelihatanlah bahwa proses pendidikan masih condong ke arah 'penindasan', belum memberikan kebebasan berkreasi kepada siswa. Proses pembelajaran masih bersifat otoriter dan konvensional, di mana siswa hanya bersifat mendengar dan menghapalkan apa yang diucapkan gurunya. Jadi, apa yang dislogankan dalam konsep KTSP yaitu pembelajaran yang menyenangkan belum tercapai. Bahkan ada istilah 'proses pembeoan' dalam dunia pendidikan. Sebagai contoh apa- 
bila seseorang mengucapkan "Selamat pagi" di hadapan seekor burung beo maka burung tersebut akan mengucapkan 'selamat pagi' pula. Tapi bagaimana jika yang diucapkan "Selamat siang? Burung beo bukan membalasnya dengan 'selamat siang', tetapi tetap mengucapkan 'selamat pagi'. Hal ini terjadi karena konsep yang ada pada “long term memory' si burung beo tadi hanya kosa kata 'selamat pagi'. Inilah proses yang masih banyak terjadi dalam proses pembelajaran di kelas.

\section{Kualitas Pendidik Masih Rendah}

Sampai saat ini masih banyak di antara guru dan dosen belum menguasai pedagogik, kurikulum termasuk silabus dan rencana pelaksanaan pembelajaran (RPP), strategi, model-model pembelajaran, merakit soal dan menguasai bahan ajarnya. Tiba saatnya di ruangan kelas, selalu bercerita mengenai pengalaman hidupnya, tidak mempunyai arah pembicaraan yang jelas.

Selain itu, banyak di kalangan guru dan dosen masih belum mampu mendudukkan dirinya sebagai pengelola proses pembelajaran (manager), menunjukkan tujuan pembelajaran (director), mengorganisasikan kegiatan pembelajaran (koordinator), mengkomunikasikan siswa dengan berbagai sumber belajar (komunikator), menyediakan dan memberikan kemudahan-kemudahan belajar (fasilitator), dan memberikan dorongan belajar (stimulator). Namun kebanyakan masih menganggap hanya gurulah yang menjadi sumber belajar tunggal (otoriter) yang harus didengar, tidak ada teori lain yang boleh diucapkan selain teori yang diberikannya.

Idealnya seorang pendidik harus profesional yang bercirikan bangun segitiga, artinya ilmu-keterampilan-etika, dan ketiganya haruslah eksis secara bersama. Penguasaan ilmu tanpa kemampuan mentransfer menjadi keterampilan, tidak ada gunanya. Berilmu dan dapat mentransformasikan menjadi keterampilan, tetapi tanpa moral atau etika, akan menjadikannya sebagai genius-terampil hewani. Kriteria 'nilai' profesional ini perlu dikedepankan, untuk melengkapi kriteria yang dirumuskan Departemen Pendidikan Nasional dalam empat hal yaitu kemampuan profesional (professional capacity), upaya profesional (professional effort), waktu yang dicurahkan (time devotion), dan imbalan atas hasil kerja (professional welfare), yang seolah-olah menganggap orang profesional adalah orang yang berpendidikan tinggi, berdasi, dan bergaji tinggi.

\section{Kondisi Sarana Pendukung Pendidikan yang Bermutu Masih Memprihatinkan}

Meskipun Pemerintah telah berusaha memaksimalkan peningkatan anggaran pendidikan hingga 20\% dari total APBN, sebagaimana amanat UUD RI 1945, namun rehabilitasi fasilitas pendidikan di berbagai daerah masih mengalami kendala serius, sehingga terdapat kasus di mana Bupati Kebumen mengagunkan Surat Keputusan Pengangkatannya sebagai bupati kepada pihak bank untuk membiayai pembangunan ulang sejumlah sekolah di kabupaten yang dipimpinnya.

Jangankan media pembelajaran seperti LCD, OHP, daerah lainnya bahkan tidak jarang ditemukan ada sekolah yang kekurangan ruangan, tanpa kursi, alat tulis, meja, dan buku pegangan siswa. Tentunya kondisi seperti ini akan memperburuk proses 
pembelajaran yang akan dilangsungkan. Bagaimana mungkin tercapai hasil belajar yang maksimal, tanpa disertai dengan sarana dan prasarana yang cukup.

\section{SIMPULAN}

Berdasarkan beberapa permasalahan yang telah dijelaskan, ada beberapa solusi pemecahan yang dapat dilakukan untuk di masa yang akan datang guna memenuhi harapan masyarakat dalam bidang pendidikan yaitu:

1. Meninjau kembali kebijakan pemerintah di bidang pendidikan yang tidak mencerminkan pemerataan pendidikan bagi seluruh masyarakat.

2. Mengusulkan penambahan pagu anggaran pendidikan yang bersumber dari APBN dan APBD.

3. Guru harus sebagai "role model": artinya pembentukan karakter pada diri siswa sesungguhnya berlangsung bukan saja melalui setiap kata yang keluar dari ucapan si guru, namun justru tumbuh melalui proses interaksi bagaimana mereka diperlakukan dan diajar oleh sang guru di kelas.

4. Meningkatkan profesionalisme guru melalui kegiatan sertifikasi dan pendidikan latihan, sehingga guru mampu sebagai agent of change melalui proses pembelajaran.

5. Membenahi segala sarana dan prasarana pendidikan.

6. Mengembangkan pendidikan berbasis masyarakat.

\section{CATATAN AKHIR:}

1. H.A.R. Tilaar, Paradigma Baru Pendidikan Nasional, Jakarta: Rineka Cipta, 2004, h. 22.

2. Yusufhadi Miarso, .Menyemai Benih Teknologi Pendidikan, Jakarta: Prenada Media, 2004, h. 267

3. Muhammad Syafei, Dasar-Dasar Pendidikan, Jakarta: Yayasan Proklamasi, 1979, h. 69 \& 92.

4. H.A.R Tilaar, op.cit., h. 21.

5. H.A.R. Tilaar, Perubahan Sosial dan Pendidikan: Pengantar Pedagogik Transformatif Untuk Indonesia, 2002, Jakarta: Grasindo, h. 325.

6. H. A. R. Tilaar, Mengindonesia Etnisitas dan Identitas Bangsa Indonesia, Jakarta: Rineka Cipta, 2007, h. 243.

7. Ibid., h. 297-311.

8. Ibid., h. 217.

\section{DAFTAR PUSTAKA:}

Nomida Musnir, Diana, Implementasi Lima Pilar Belajar Dalam Pendidikan IPS, Yogyakarta, 2008. Miarso, Yusufhadi, .Menyemai Benih Teknologi Pendidikan, Jakarta: Prenada Media, 2004.

Syafei, Muhammad, Dasar-Dasar Pendidikan, Jakarta: Yayasan Proklamasi, 1979.

Tilaar, H.A.R., Perubahan Sosial dan Pendidikan: Pengantar Pedagogik Transformatif Untuk Indonesia, Jakarta: Grasindo, 2002.

Tilaar, H.A.R., Paradigma Baru Pendidikan Nasional, Jakarta: Rineka Cipta, 2004.

Tilaar, H.A.R., Mengindonesia Etnisitas dan Identitas Bangsa Indonesia, Jakarta: Rineka Cipta, 2007. 